\title{
SMALL AND ISOLATED: ECOLOGY AND FRAGMENTATION OF NEANDERTHALS
}

\author{
Marina Melchionna (우 \\ ${ }^{1}$ Dipartimento di Scienze della Terra, dell'Ambiente e delle Risorse, Università degli Studi di Napoli Federico II, Italy; marina.melchionna@, \\ unina.it
}

\section{KeYwORDS:}

Homo neanderthalensis; Species distribution modelling; fragmentation.

\section{Bullet-Points Abstract}

- Homo sapiens greater ecological plasticity allowed this species to react better to climate changes

- AMHs maintained a more continuous occupation of its potential habitat

- Habitat reduction and fragmentation in Homo neanderthalensis must have had dramatic consequences on its population size.

\section{INTRODUCTION}

Neanderthals lived in Eurasia alongside anatomically modern humans (AMHs). The oldest evidence of a Neanderthal population was found at Zuttiyeh (Israel), with an age around 200,000 years ago, Tabun (Mount Carmel, Israel) around 150,000 years (Grun et al., 1991) and Altamura (Italy) at around 150,000 years (Lari et al., 2015). Neanderthals present unique morphological characteristics that make them very different from AMHs. They had a large nasal cavity, reduced chin, and short limb proportions suggesting a limited stature (Helmuth, 1998). Moreover, Neanderthals had a wide chests and large lung volume (Franciscus \& Churchill, 2002; Macias \& Churchill, 2015). For years scientists considered these features as adaptions to cold climates. Higham and colleagues (2014) statistically placed the extinction of Homo neanderthalensis King, 1864 around $40 \mathrm{ka}$, almost in coincidence with Heinrich Event 4 (HE4). This event consists in a sudden and global shift towards colder temperatures (Van Meerbeeck et al., 2009).

It has been demonstrated that Neanderthal populations experienced major demographic contractions during the HE4 cold event in Northern Iberia and Southern France (d'Errico \& Goñi 2003; Sepulchre et al., 2007). This evidence shows that, contrary to the previous assumptions, the Neanderthal is not an ice age species. There are different works that seem to support this hypothesis (Finlayson \& Giles, 2000; Stewart, 2004; 2007; Bradtmöller et al., 2012).

The late contraction of $H$. neanderthalensis range to southern Europe coincides with the spread of AMHs, suggesting a possible instance for competitive exclusion between the two (Banks et al., 2008; Mellars \& French, 2011). Negative interactions between Neanderthals and AMHs are often viewed as the potential drivers of $H$. neanderthalensis extinction, as an alternative to climate change hypothesis, or a combination of the two causes (Rey-Rodríguez et a1., 2016).

Melchionna and colleagues (2018) used Species Distribution Modelling (SDM) to quantify and compare statistically the inferred climatic niches of Homo sapiens Linnaeus, 1758 and H. neanderthalensis in Western Eurasia during the last $8 \mathrm{ka}$ of Neanderthals existence. The aim of that work was to evaluate the niche evolution

and overlap in the two species, identifying their optimal habitat patches and to which degree these patches connected to each other.

\section{Materials ANd Methods}

As first step, we used fossil occurrence records (the Stage Three Project archaeological database, van Andel, 2002; the Canadian Archaeological Radiocarbon Database, Gajewski et al., 2011; the Radiocarbon Palaeolithic Europe Database, Vermeersch, 2017) and paleoclimatic data (Singarayer \& Valdes, 2010). Both fossil and archaeological occurrences were used. Only radiocarbon records computed by using Accelerator Mass Spectrometry (AMS) were taken into account. Dates were calibrated under the 'IntCal13' curve, by using the R package 'Bchron' (Parnell, 2016). The framework was divided in three different temporal windows, at $48 \mathrm{ka}, 44 \mathrm{ka}$ and $44 \mathrm{ka}$ ago.

To model the potential distributions of $H$. sapiens and $H$. neanderthalensis we used Species Distribution Models (SDMs) These models allow to combine both occurrences and climatic information to compute the potential habitat of the species (Maiorano et al., 2013). The final product of this procedure is a suitability map. Suitability can be defined as a measure of how much the habitat is suitable for a species to occur in a given place and during a given time. The SDMs computation was performed under the R software environment.

After that, we evaluated the degree of structural con- 

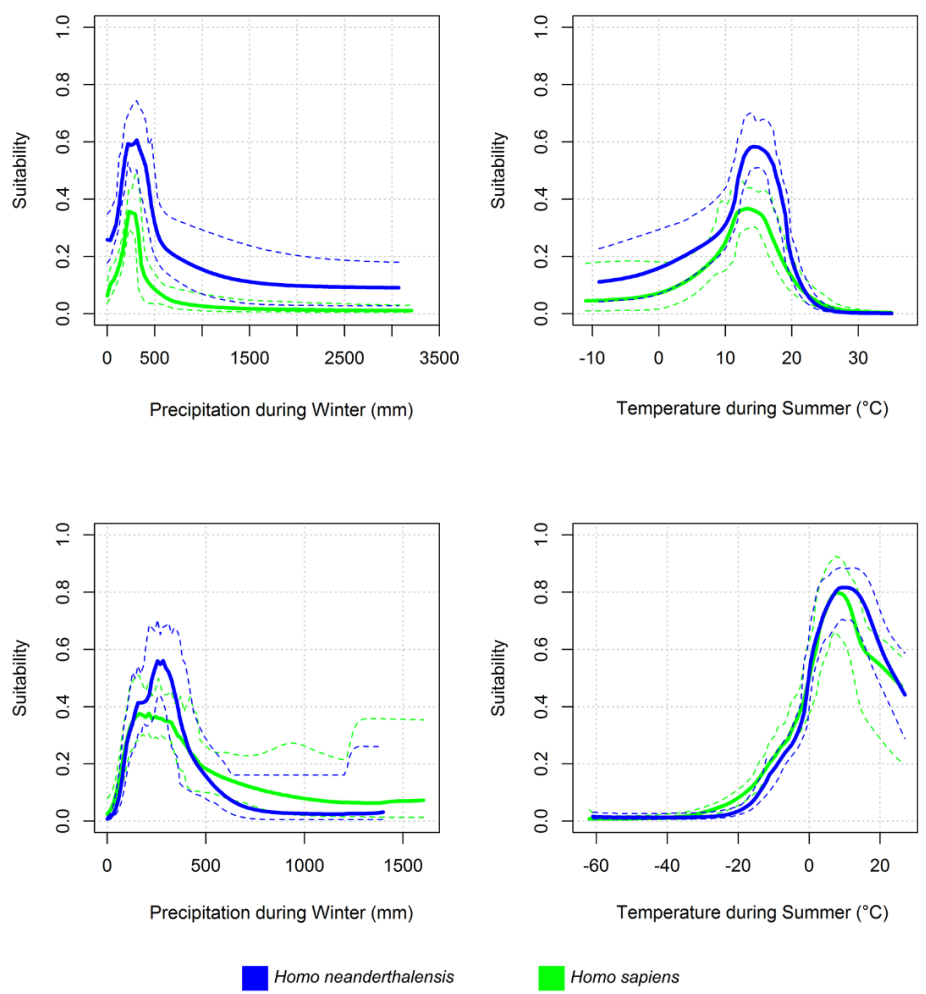

Fig. 1. Suitability analysis results. Response curves depict the variation of the probability of presence versus each variable. Blue (green) curves referring to $H$. neanderthalensis (H. sapiens). Dotted lines represent the range interval over the $100 \mathrm{SDMs}$ run per species in order to account for dating uncertainty.

nectivity between optimal habitat patches as predicted by SDMs for the two species separately, focussing on different landscape metrics describing the number of Patches, their area and degree of connection.

\section{Results AND Discussions}

The suitability analysis showed that Neanderthal suitability is higher for 3 out of 4 climatic predictors (Fig. 1 ), meaning that $H$. neanderthalensis was better than H. sapiens at his climatic optimum. This is not surprising, because Neanderthals originated in Eurasia, so they were well adapted to this climatic condition. Response curves of both species are highly overlapping, suggesting close similarity between Neanderthals' and AMH's potential climatic preferences. However, looking at the tails of the distribution, it can be noticed that $H$. sapiens curves offset those of $H$. neanderthalensis for three of four predictors, namely temperature during summer and both precipitation variables, suggesting a wider tolerance to these predictors for $\mathrm{H}$. sapiens (Fig 1).

The connectivity analysis showed an increase in occupied patches toward the present, but in Neanderthals only, while the number of patches occupied by $H$. sapiens remains stable (Fig. 2, top). At the same time, the whole range of $H$. neanderthalensis decreases through the process. The patches occupied by Neanderthals thus became smaller and more isolated (Fig.
2 , bottom). This is true especially for the 44 and the 40 ka temporal windows.

Our findings seem to confirm the hypothesis of a regional extinction model for North-Western Neanderthal populations in the coldest (Northern) stretches of its habitat (Hublin \& Roebroeks, 2009), before the full spread of AMHs in Europe, placed around $42 \mathrm{ka}$ (Benazzi et al., 2015). Benito et al. (2017) recently demonstrated $H$. neanderthalensis most suitable environment during the Eemian was the Mediterranean area, while mountain ranges and continental plains showed low habitat suitability. Our data strongly concur on these findings. Genetic and demographic data also are consistent with these notions. Neanderthals were found to have had small population size and high mortality rates (Trinkaus, 1995; Sørensen, 2011; Bocquet-Appel \& Degioanni, 2013).

It appears clear that the climate change played a fundamental role in Neanderthals demise. At the same time, the presence of AMHs in Europe could have been limited the latest Neanderthal populations as well. However, a real process of habitat fragmentation occurred in the $H$. neanderthalensis population and it must have had dramatic consequences on its size.

\section{Conclusions}

Our findings show that $H$. sapiens had greater ecological plasticity over Neanderthals, which probably al- 


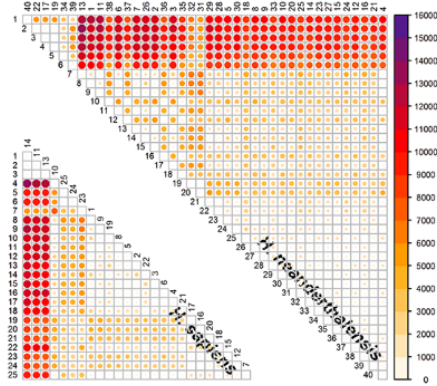

48 ka

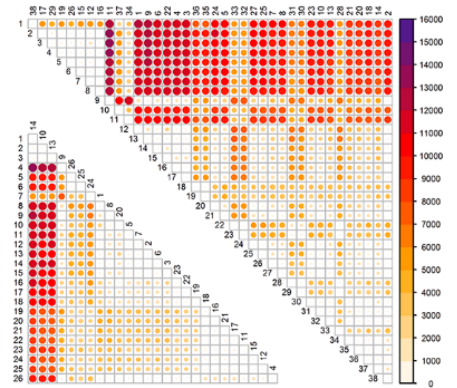

44 ka

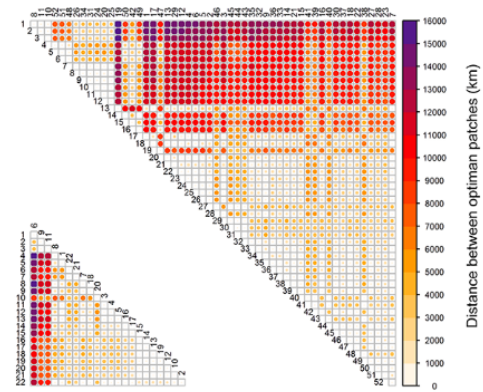

40 ka
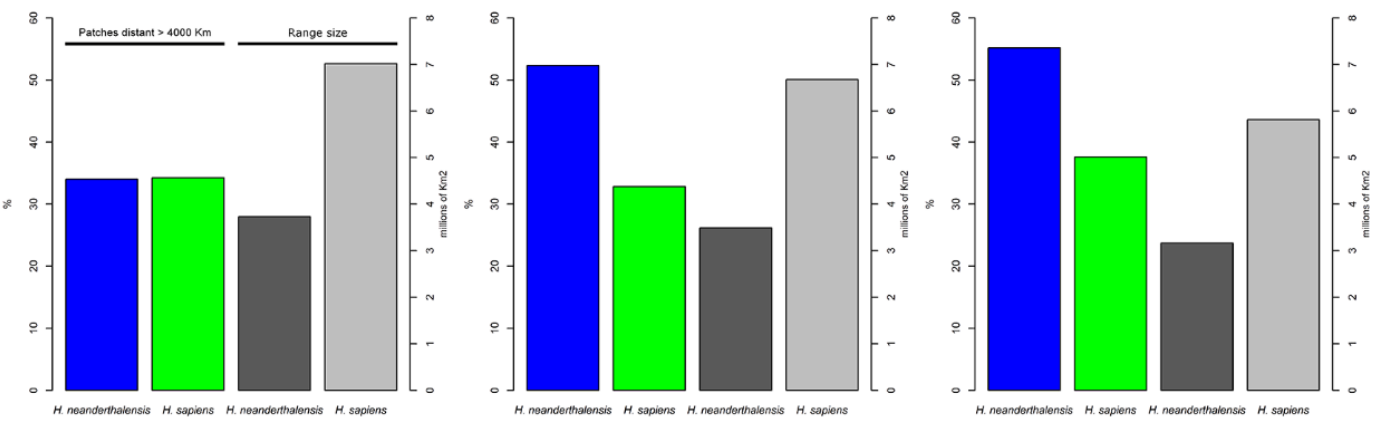

Fig. 2. Evolution of optimal habitats in Neanderthals and AMHs. Dots represent the linear distance in kilometers between optimal patches pairs (i.e. above the 95th percentile of the suitability values predicted by the ensemble forecasting). Distance increases from white to purple and is proportional to dots size. Row and column numbers refer to the individual patch ID. Blue (green) columns in bar plots summarize the percentage of optimal patches pairs $>4000 \mathrm{~km}$ apart for $\mathrm{H}$. neanderthalensis $(\mathrm{H}$. sapiens) in the three time points. Dark grey (light grey) bars indicate range size of $H$. neanderthalensis (H. sapiens) in millions square kilometres.

lowed this species to better react to climatic worsening at 44 and then at $40 \mathrm{ka}$. On the contrary, Neanderthals potential habitat appear to be very reduced and fragmented during the last phase of their occupation. Moreover, habitat reduction and fragmentation in $H$. neanderthalensis suggest its population became unfit to recover in the wake of climatic change.

\section{ACKNOWLEDGEMENTS}

The author is grateful to Andrew Martindale for sharing with us the CARD data. Anna Loy provided important insights about the idea at the base of this study.

\section{REFERENCES}

Banks W. E., d'Errico F., Peterson A. T., Kageyama M., Sima A. \& Sánchez-Goñi M. F. (2008). Neanderthal extinction by competitive exclusion. PLoS One, 3: e3972.

Benazzi S., Slon V., Talamo S., Negrino F., Peresani M., Bailey S. E., Sawyer S., Panetta D., Vicino D., Starnini E., Mannino M. A., Salvadori P.A., Meyer M., Pääbo S. \& Hublin J.-J. (2015). The makers of the Protoaurignacian and implications for Neandertal extinction. Science, aaa2773.

Benito B. M., Svenning J.C., Kellberg-Nielsen T., Riede F., Gil-Romera G., Mailund T., Kjaergaard P.C., \& Sandel B.S. (2017). The ecological niche and distribution of Neanderthals during the Last Interglacial. Journal of Biogeography. 44: 51-61.

Bocquet-Appel J. P. \& Degioanni A. (2013). Neanderthal demographic estimates. Current Anthropology, 54(S8): S202-S213.

Bradtmöller M., Pastoors A., Weninger B. \& Weniger G.-C. (2012). The repeated replacement model - rapid climate change and population dynamics in Late Pleistocene Europe. Quaternary International 247: 38-49.

d'Errico F. \& Goñi M. F. S. (2003). Neandertal extinction and the millennial scale climatic variability of OIS 3. Quaternary Science Reviews, 22(8-9): 769-788.

Finlayson C., Giles-Pacheco F. (2000). The southern Iberian Peninsula in the late Pleistocene: geography, ecology, and human occupation. In Stringer, C. B., Barton, R. N. E., Finlayson, J. C. (eds.), Neanderthals on the Edge. Oxbow Books, Oxford, pp. 139-159.

Franciscus R. G. \& Churchill S. E. (2002). The costal skeleton of Shanidar 3 and a reappraisal of Neandertal thoracic morphology. Journal of human evolution, 42(3): 303-356.

Gajewski K., Muñoz S., Peros M., Viau A., Morlan R. \& Betts M. (2011). The Canadian archaeological radiocarbon data-base (CARD): archaeological 14C dates in North America and their paleoenvironmental context. Radiocarbon, 53: 371-394.

Grun R., Stringer C. B. \& Schwarcz H. P. (1991). ESR dating of teeth from Garrod's Tabun cave collection. Journal of Human Evolution, 20(3): 231-248.

Helmuth H. (1998). Body height, body mass and surface area of the Neandertals. Zeitschrift für Morphologie und Anthropologie, 1-12.

Higham T., Douka K., Wood R., Ramsey C.B., Brock F., Basell L., Camps M., Arrizabalaga A., Baena J., Bar- 
roso-Ruíz C., Bergman C., Boitard C., Boscato P., Caparrós M., Conard N.J., Draily C., Froment A., Galván B., Gambassini P., Garcia-Moreno A., Grimaldi S., Haesaerts P., Holt B., Iriarte-Chiapusso M.-J., Jelinek A., Pardo J.F.J., Maíllo-Fernández J.-M., Marom A., Maroto J., Menéndez M., Metz L., Morin E., Moroni A., Negrino F., Panagopoulou E., Pe-resani M., Pirson S., la Rasilla de M., Riel-Salvatore J., Ronchitelli A., Santamaria D., Semal P., Slimak L., Soler J., Sol-er N., Villaluenga A., Pinhasi R. \& Jacobi R. (2014). The timing and spatiotemporal patterning of Neanderthal disappear-ance. Nature, 512: 306-309. doi:10.1038/nature13621

Hortolà P. \& Martínez-Navarro B. (2013). The Quaternary megafaunal extinction and the fate of Neanderthals: An integra-tive working hypothesis. Quaternary International. 295, 69-72. doi:10.1016/j.quaint.2012.02.037

Hublin J.-J. \& Roebroeks W. (2009). Ebb and flow or regional extinctions? On the character of Neandertal occupation of northern environments. Comptes Rendus Palevol, 8: 503-509.

Lari M., Di Vincenzo F., Borsato A., Ghirotto S., Micheli M., Balsamo C., Collina C., De Bellis G., Frisia S., Giacobini g., Gigli E., Hellstrom J.C., Lannino A., Modi A., Pietrelli A., Pilli E., Profico A., Ramirez O., Rizzi E., Vai S., Venturo D., Piperno M., Lalueza-Foz C., Barbujani G., Caramelli D. \& Gigli, E. (2015). The Neanderthal in the karst: first dating, morphometric, and paleogenetic data on the fossil skeleton from Altamura (Italy). Journal of Human Evolution, 82: 88-94.

Linnaeus C. (1758) - Systema Naturae per regna tria naturae, secundum Classes, Ordines, Genera, Species, cum characteribus, differentiis, synonymis, locis. Tomus I, 10th edition: Holmiae, Laurentius Salvius, Stockholm, Sweden, $824 \mathrm{p}$.

Maiorano L., Cheddadi R., Zimmermann N. E., Pellissier L., Petitpierre B., Pottier J., Laborde H., Hurdu B. I., Pearman P. B., Psomas A., Singarayer J. S., Broennimann O., Vittoz P., Dubuis A., Edwards M. E., Binney H. A. \& Guisan A. (2013). Building the niche through time: using 13,000 years of data to predict the effects of climate change on three tree species in Europe. Global Ecology and Biogeography. 22: 302-317.

McGarigal K., Cushman S. A. \& Ene E. (2012). FRAGSTATS v4: spatial pattern analysis program for categorical and continuous maps. In Computer Software Program Produced By the Authors at the University of Massachusetts, Amherst.

Melchionna M., Di Febbraro M., Carotenuto F., Rook L., Mondanaro A., Castiglione S., Diniz-Filho J. A. F. \& Raia P. (2018). Fragmentation of Neanderthals' pre-extinction distribution by climate change. Palaeogeography, Palaeoclimatology, Palaeoecology, 496: 146-154.

Mellars P. \& French J. C. (2011). Tenfold population increase in western europe at the neandertal-to-modern human transition. Science, 333(6042): 623-627.

Parnell A. (2016). Bchron: radiocarbon dating, age-depth modelling, relative sea level rate estimation, and non-parametric phase modelling. In $\mathrm{R}$ package Version 4.1.1 (2015).

Rey-Rodríguez I., López-García J. M., Bennàsar M., Bañuls-Cardona S., Blain H. A., Blanco-Lapaz A. Rodríguez-Álvarez X. P., de Lombera-Hermida A., Díaz-Rodríguez M., Ameijenda-Iglesias A., Agustí J. \& Fábregas-Valcarce R. (2016). Last Neanderthals and first Anatomically Modern Humans in the NW Iberian Peninsula: Climatic and environmen-tal conditions inferred from the Cova Eirós small-vertebrate assemblage during MIS 3. Quaternary Science Review, 151: 185-197.
Sepulchre P., Ramstein G., Kageyama M., Vanhaeren M., Krinner G., Sánchez-Goñi M.-F. \& D'errico F. (2007). H4 abrupt event and late Neanderthal presence in Iberia. Earth and Planetary Science Letters, 258: 283-292.

Singarayer J. S. \& Valdes P. J. (2010). High-latitude climate sensitivity to ice-sheet forcing over the last 120kyr. Quaternary Science Review, 29: 43-55. doi:10.1016/j.quascirev.2009.10.011

Sørensen B. (2011). Demography and the extinction of European Neanderthals. Journal of Anthropological Archaeo$\log y, 30(1): 17-29$.

Stewart J. R. (2004). Neanderthal-modern human competition? A comparison between the mammals associated with Mid-dle and Upper Palaeolithic industries in Europe during OIS 3. International Journal of Osteoarchaeol. 14: 178-189. doi: 10.1002/oa.754

Stewart J. R. (2007). Neanderthal extinction as part of the faunal change in Europe during Oxygen Isotope Stage 3. Acta Zoologica Cracoviensia - Series A: Vertebrata, 50A: 93-124. doi:10.3409/000000007783995372

Trinkaus E. (1995). Neanderthal mortality patterns. Journal of Archaeological Science, 22(1): 121-142.

van Andel T. H. (2002). The Climate and Landscape of the Middle Part of the Weichselian Glaciation in Europe: The Stage 3 Project. Quaternary Research, 57: 2-8. doi:10.1006/qres.2001.2294

Van Meerbeeck C. J., Renssen H. \& Roche D. M. (2009). How did Marine Isotope Stage 3 and Last Glacial Maximum cli-mates differ?-perspectives from equilibrium simulations. Climate of Past, 5: 33-51.

Vermeersch P. M. (2017). Radiocarbon Palaeolithic Europe Database, Version 24. Available at: http://ees.kuleuven.be/geography/projects/14c-palaeolithic/index. html

\author{
Manuscript received 5 August 2018 \\ Received after revision 16 October 2018 \\ Accepted 22 October 2018
}

